\title{
Demineralization mechanism and influence of parameters on high ash Indian coal by chemical leaching of acid and alkali solution
}

\author{
Sushanta K. Behera ${ }^{1}$ Sudipto Chakraborty ${ }^{1}$ B. C. Meikap ${ }^{1,2}$
}

Received: 10 January 2018/Revised: 17 April 2018/ Accepted: 31 May 2018/Published online: 12 June 2018

(C) The Author(s) 2018

\begin{abstract}
The current research was investigated the mechanism of coal demineralization and the effect of leaching parameters on high ash coal and study the characterization of pre and post-treated coal. The two high ash Indian coal selected from Mahanadi Coalfield Limited, Odisha, pulverized to 375, 230 and $180 \mu \mathrm{m}$ particle size were undergone simultaneous acid and alkali treatment at a different concentration, temperature and time. The percent demineralization was increased with decrease the size of the particle and rises with leaching parameters. The investigation suggested $180 \mu \mathrm{m}$ particle size offers efficient demineralization for both coals at $30 \% \mathrm{NaOH}$ and $30 \% \mathrm{H}_{2} \mathrm{SO}_{4}$ concentration. The alkali leaching leads to obtaining the demineralization $46 \%$ and $42 \%$ whereas acid treatment resulted in $34 \%$ and $32 \%$ of the original coal samples. The extent of demineralization was improved the calorific value of coal. Besides, the degree of demineralization was proved from the FTIR, XRF and FESEM-EDX analysis results. FTIR analysis result showed that the peak intensity of mineral band decreased by the leaching effect and the degree of demineralization was significantly obtained to large extent by the X-ray Fluorescence spectrometer; which elucidates major minerals removed from coal by the leaching effect of acid and alkali solution.
\end{abstract}

Keywords High ash coal $\cdot$ Leaching $\cdot$ Mineral matter $\cdot$ Demineralization $\cdot$ Calorific value

\section{Introduction}

Coal is the largest fossil fuel abundantly distributed in many parts of the world. The demand of energy and the depletion of high-quality coal, so more attention is focused on utilization of the low- grade coal. The low-grade coal has a serious deficiency to utilization because it associated with high mineral matter content and moisture content. The origin of Indian coal is heterogeneous in nature and

Sushanta K. Behera

skbehera@che.iitkgp.ernet.in

1 Department of Chemical Engineering, Indian Institute of Technology (IIT) Kharagpur, Kharagpur, West Bengal 721302, India

2 Department of Chemical Engineering, School of Chemical Engineering, Howard College Campus, University of Kwazulu-Natal (UKZN), Durban 4041, South Africa consists of the complex mixture of organic (carbon) and inorganic (minerals) constituents (Georgakopoulos et al. 2003). The use of low-grade coal in large-scale unit leads to environmental pollution due to generation of the solid wastes and gaseous pollutants. It causes the increase cost of the power plants, reduce the efficiency and produces technical difficulties during processes and production steps (Meshram et al. 2015). It is necessary to demineralize and desulphurize such coal before using in thermal power station, steel plants, or cement industries, etc. The major minerals commonly found in coal are quartz and other forms of silica, clay mineral, pyrites and carbonates such as siderites and ankerites (Mukherjee and Borthakur 2001). The coal ash formed from mineral matter is both organic and inorganic in nature. High ash ( $>20 \%$ weight) coal is rich with mineral content such as quartz, illite, calcite, pyrite, gypsum, and elements like $\mathrm{H}, \mathrm{N}, \mathrm{S}$ and oxygen. The high ash coal is always enriched with oxides of $\mathrm{SiO}_{2}$, $\mathrm{Fe}_{2} \mathrm{O}_{3}, \mathrm{Al}_{2} \mathrm{O}_{3}$, and $\mathrm{K}_{2} \mathrm{O}$ (Ciu et al. 2015). The cleaning of 
coal can be achieved by both physical and chemical method (Gulen et al. 2005). The degree of demineralization of coal by various method mostly depends on the percentage and composition of mineral matter, their types, and association within the raw coal. The physical methods are based on the difference in their physical properties (specific gravity and surface properties) of the minerals and the carbonaceous part of the coal (Behera et al. 2017a, b). The chemical method involve treatment with different chemical solvent are used for removing mineral matter, like the finely distributed mineral and those bound strongly to the coal matrix (Ma et al. 2014). The purpose of beneficiation of a low-grade coal is to reduce inert content for easy transportation, minimize abrasive materials and to improve the combustion qualities. The combustion properties of coal like heating value, volatile matter content that govern the performance of coal have a clear dependence on ash, maceral composition. Therefore, more emphasis is given for the cleaning method of coal so that it may minimize the mineral matter and improve the quality of coal. However, chemical cleaning processes are more expensive than physical cleaning steps in terms of total cost (Dash et al. 2015a, b). The chemical beneficiation methods are include acid leaching, alkali leaching, acid leaching followed by alkali leaching or alkali leaching followed by acid leaching and leaching by molten caustic treatment. The coal cleaning by the chemical method is a simple process when it is operates under mild condition. Chemical leaching process usually achieved remove all types of minerals from the coal compared to physical treatment method. Although, chemical cleaning method has not been widely employed on a commercial scale due to huge cost related to the requirement of chemical and need for dewatering and regeneration of reagents from spent solution (Wu and Steel 2007; Waugh and Bowling 1984; Ryberg et al. 2015; Sriramoju et al. 2017).

A review of the literature was studied for demineralization of high ash coal by treated with acid and alkali solution at different physical parameter. The effect of temperature, caustic concentration and time on the degree of demineralization of Turkish low and high grade lignite coal was studied by Culfaz et al. The high ash coal from Beypazari (35.6\% ash), and low ash coal from Soma (7\% ash) are treated with caustic soda and washed with $\mathrm{HCl}$ solution. In the effect of caustic treatment, most of the silica $\left(\mathrm{SiO}_{2}\right)$ and calcium oxide $(\mathrm{CaO})$ in the ash were removed. However, the iron oxide $\left(\mathrm{Fe}_{2} \mathrm{O}_{3}\right)$ and sodium oxide $\left(\mathrm{Na}_{2} \mathrm{O}\right)$ remained in the coal matrix. The percent demineralization was obtained $90 \%$ from both the coal seams (Culfaz et al. 1996). Sharma and Gihar reported the effect of dilute aqueous $\mathrm{NaOH}$ solution followed by $10 \%$ aqueous $\mathrm{HCl}$ or $\mathrm{H}_{2} \mathrm{SO}_{4}$ at mild condition under atmospheric pressure. In this investigation, $75 \mathrm{wt} \%$ demineralization was achieved with these chemical solvents (Sharma and Gihar 1991). Karaca and Ceylan studied the leaching effect of hydrogen peroxide $\left(\mathrm{H}_{2} \mathrm{O}_{2}\right)$ on Turkish two lignites (Beypazari and Tuncbilek seam). They investigated the effect of concentration, contact time and temperature on the removal of ash and sulphur. The demineralization was achieved from $30 \%$ to $70 \%$ from lignite coal type from the investigation (Karaca and Ceylan 1997). Onal and Ceylan studied six Turkish lignite coal were treated with $\mathrm{HCl}$ or EtONa solution at $150{ }^{\circ} \mathrm{C}$. They concluded from the investigation, $\mathrm{HCl}$ treatment was effective demineralization but not with EtONa while efficient desulphurization was achieved by EtONa treatment but not with $\mathrm{HCl}$ (Onal and Ceylan 1995). Adeleke et al. studied the effect of multistage caustic leaching of Nigerian LafiaObi coal. The average ash reduction was achieved $38.66 \%$ at low molar concentration of 1:20 mass reagent $\left(\mathrm{H}_{2} \mathrm{O}-\right.$ $\mathrm{Na}_{2} \mathrm{CO}_{3}-\mathrm{H}_{2} \mathrm{O}$ ) to coal in the absence of stirring (Adeleke et al. 2011). The ammonia $\left(\mathrm{NH}_{3}\right)$ treated coal was reacted with the mixture of concentrated sulfuric acid and calcium fluoride in a two-stage process at temperature $350{ }^{\circ} \mathrm{C}$. Low demineralization (13\%) was obtained in the two-stage process in comparison to only ammonia-treated coal and $70 \%$ demineralization was achieved (Choudhury and Bhaktavatsalam 1997). Nabeel et al. studied sequential leaching of power grade coal with $\mathrm{NaOH}-\mathrm{H}_{2} \mathrm{SO}_{4}$ and obtained more than $50 \%$ degree of demineralization and also regenerate the leachate by treated with lime and silicic acid (Nabeel et al. 2009). The mineral matter of high ash bituminous coal was studied by Bolat et al. (1998), using different acid $\mathrm{HF}, \mathrm{HCl}, \mathrm{HNO}_{3}$ and $\mathrm{H}_{2} \mathrm{SO}_{4}$ alone and $0.5 \mathrm{~N}$ (Normality) aqueous $\mathrm{NaOH}$ combination and obtained $47 \%$ maximum degree of mineralization. Mukherjee et al., studied the Boragolai and Ledo coal seam of Makum Coal Field (Assam) were treated with potassium hydroxide and followed with $\mathrm{HCl}$. The demineralization of coal were enhanced $28 \%-45 \%$ to $39 \%-68 \%$ at 95 and $159{ }^{\circ} \mathrm{C}$ respectively (Mukherjee and Borthakur 2003).

A literature review revealed that the chemical leaching process may improve the demineralization of coal. The demineralization study of coal has been investigated mostly with low ash coal to generate ultra-clean coal. Since the Indian coals are high ash content and the nature of low ash coal is completely different from Indian coal. In this paper, it has been shown the alkali $(\mathrm{NaOH})$ is efficient demineralized the low grade coal than sulfuric acid $\left(\mathrm{H}_{2} \mathrm{SO}_{4}\right)$ reagent because of the presence of hydroxyl ion in caustic which caused the high affinity towards the major elements present in the coal. The current paper was investigated with two objectives. The first objective of the research was to find the dissolution mechanism of minerals in the coal and effect of leaching parameters on the demineralization by treating with the chemical solvents $(\mathrm{NaOH}$ 
and $\mathrm{H}_{2} \mathrm{SO}_{4}$ ). The second objective is to study the improvement the carbon content of original coal from the characterization. In addition to the study, the characterization of pre and post-treated coal has been investigated in FTIR, XRF and FESEM-EDX analysis, in order to check the confirmation of the coal demineralization.

\section{Materials and method}

\subsection{Materials}

In this study, the two high ash coal samples were selected from Bharatpur (Coal A) and Ananta (Coal B) coal seams of Mahanadi Coalfield Limited (MCL), Talcher, Odisha. According to geological survey of India, it is the major producing thermal power coal. The raw coal samples were crushed and sieved in British standard sieve (BSS) mesh size to select the particle size 375,230 and $180 \mu \mathrm{m}$ for experimental study. The required size of coal samples were preserved in desiccators before the start of the experiment. The commercially available chemical solvents like sodium hydroxide $(\mathrm{NaOH})$ and Sulfuric acid $\left(\mathrm{H}_{2} \mathrm{SO}_{4}\right)$ were used as leachant in the experiments.

\subsection{Chemical analysis of coal}

The ultimate analysis of raw coal was measured by a LECO-CHNS 932 Elemental Analyzer. On the dry ash free basis, to determine the $\mathrm{C}, \mathrm{H}, \mathrm{N}$ and $\mathrm{S}$ contents in the coal samples, while the oxygen $\left(\mathrm{O}_{2}\right)$ content calculated by difference. Proximate analysis data on a dry basis were determined by using a Muffle furnace to measure the volatile matter, ash while the fixed carbon was determined by difference followed by standard ASTM methods (ASTM D3173 2011; ASTM D3174 2011; ASTM D3175 2011). The calorific value was determined using the high- pressure oxygen bomb calorimetric method following ISO 1928 method. The results were shown in Tables 1 and 2 .

\subsection{X-ray fluorescence analysis of coal}

$\mathrm{X}$-ray fluorescence (XRF) spectrometry is a rapid technique for accurate and precise elemental analysis of solid and liquid specimens. The composition of mineral matter as a fraction of oxide and trace elements in the pre and post-treated coal samples were analyzed in XRF spectrometer (PANalytical AXIOS FAST XRF spectrometer, Japan). The pelletization was prepared by pressed powder method. In an aluminum cylindrical die, filling $2 \mathrm{~g}$ of boric acid powder and mixed with $4 \mathrm{~g}$ of powder coal ash sample. The mixture was pressed into a pellet on a hydraulic pelleting machine. Finally, the pellet was used for the composition of ash analysis.

\subsection{Fourier transform infrared spectrometer}

FTIR (Fourier transform infrared) spectroscopy is a powerful tool for the characterization of coal and its products as it signifies the comprehensive view about the structure/composition of the minerals in the coal matrix. Infrared (IR) spectroscopy is the study of the interaction between the matter and electromagnetic field in the IR region. The probability of a particular IR frequency being absorbed depends on the actual interaction between the frequency and the molecule. Planck energy relation is used for calculating the energy of an infrared photon using, $E=$ $h v$, where $h$ (Planck's constant) $=6.6 \times 10^{-34} \mathrm{Js}$ and $v=$ frequency of the photon $\left(\mathrm{s}^{-1}\right)$. The frequency $(v)$ and speed of light (c) are related to the relation, $c=\lambda v$, where $c=3 \times 10^{8} \mathrm{~m} / \mathrm{s}$ and $\lambda=$ wavelength of the light. The $\mathrm{c}$ and $E$ are correlated to a standard spectroscopic unit called wave number $\left(\bar{v} \mathrm{~cm}^{-1}\right)$, it is the reciprocal of the wavelength. $E=\frac{h c}{\lambda}=h c \bar{v}$, both frequency and wave number are

Table 1 Proximate analysis of used coal

\begin{tabular}{|c|c|c|c|c|c|c|}
\hline \multirow{3}{*}{$\begin{array}{l}\text { Item } \\
\text { value }(\%)\end{array}$} & \multicolumn{6}{|c|}{ Proximate analysis (on dry basis) } \\
\hline & \multicolumn{3}{|l|}{ Coal A } & \multicolumn{3}{|l|}{ Coal B } \\
\hline & $375 \mu \mathrm{m}$ & $230 \mu \mathrm{m}$ & $180 \mu \mathrm{m}$ & $375 \mu \mathrm{m}$ & $230 \mu \mathrm{m}$ & $180 \mu \mathrm{m}$ \\
\hline Volatile matter & 35.93 & 33.92 & 35.65 & 33.86 & 33.51 & 30.93 \\
\hline Fixed carbon & 25.96 & 27.72 & 25.47 & 26.06 & 25.92 & 25.39 \\
\hline Ash & 38.11 & 38.36 & 38.88 & 40.08 & 40.57 & 43.68 \\
\hline
\end{tabular}


Table 2 Ultimate analysis of used coal

\begin{tabular}{|c|c|c|c|c|c|c|}
\hline \multirow{3}{*}{$\begin{array}{l}\text { Item } \\
\text { value }(\%)\end{array}$} & \multicolumn{6}{|c|}{ Ultimate analysis (on dry ash free basis) } \\
\hline & \multicolumn{3}{|l|}{ Coal A } & \multicolumn{3}{|l|}{ Coal B } \\
\hline & $375 \mu \mathrm{m}$ & $230 \mu \mathrm{m}$ & $180 \mu \mathrm{m}$ & $375 \mu \mathrm{m}$ & $230 \mu \mathrm{m}$ & $180 \mu \mathrm{m}$ \\
\hline Carbon $(\mathrm{C})$ & 40.55 & 43.74 & 39.99 & 41.34 & 41.54 & 40.36 \\
\hline Hydrogen $\left(\mathrm{H}_{2}\right)$ & 3.257 & 3.44 & 3.267 & 3.105 & 3.225 & 3.206 \\
\hline Nitrogen $\left(\mathrm{N}_{2}\right)$ & 2.44 & 2.56 & 2.28 & 2.21 & 2.51 & 2.43 \\
\hline Sulfur (S) & 0.382 & 0.447 & 0.562 & 0.433 & 0.402 & 0.348 \\
\hline Oxygen $\left(\mathrm{O}_{2}\right.$ diff. $)$ & 53.371 & 49.813 & 53.901 & 52.912 & 52.323 & 53.656 \\
\hline
\end{tabular}

directly proportional to energy and this indicates higher the energy photons have higher the frequency (Sahoo et al. 2015). The presence of functional group and bonding characteristic of the raw and upgraded coals were determined through FTIR measurements using a Nicolet NEXUS-670 FTIR instrument. In the presence of baking lamp, approximately $1 \mathrm{mg}$ of ground coal sample was properly mixed with $100 \mathrm{mg}$ of dried $\mathrm{KBr}$ powder then it ground and pestle with mortar to avoid moisture absorption. The mixture was pressed into a pellet on a hydraulic pelleting machine. The software used for data processing and spectral analysis. To access the presence functional groups in the sample FTIR analysis was performed.

\subsection{FESEM-EDX analysis}

The scanning electron microscopy coupled with energy dispersive X-ray (SEM-EDX) analysis were used to determine the nature of mineral matter of the pre and posttreated coal samples by Field Electron Scanning Electron Microscope (FESEM) model JEOL JSM-7610F, Japan. SEM samples were prepared by sprinkling powdered coal sample on to a carbon coated metallic holder followed by gold coating. The reason for gold coating used to make the conducting behaviour of coal samples.

\subsection{Experimental method}

In the present study, the leaching experiments were carried out in a batch reactor of capacity 1.5-2.5 L with heating facilities, condenser provision for reflux and temperature measured by a thermometer. The batch reactor made up stainless steel reactor (SS-316) which consist of $0.11 \mathrm{~m}$ diameter and $0.22 \mathrm{~m}$ height with Teflon coating inside. The reactor is heated with three heating coils of $1 \mathrm{KW}$ capacity each, which fitted outside of the circumference of the reactor. A stainless steel stirrer is firmed in motor and whose propeller placed at $0.06 \mathrm{~m}$ above from the bottom of the reactor. A motor moves the stirrer and its speed measured by the sensor that mounted in front of the motor. The stirrer usually operates at 600-900 rpm. The comminution of lumped coal samples and the leaching experimental set up as shown in Fig. 1. Initially, the coal sample of respective particle size treated with deionized water, and then $20 \%, 30 \%$ concentration (by vol\%) of $\mathrm{H}_{2} \mathrm{SO}_{4}$ and $\mathrm{NaOH}$ (by wt\%) solution at temperature $100{ }^{\circ} \mathrm{C}$ for $90 \mathrm{~min}$. In another, a series of experiment was conducted at a fixed concentration ( $10 \%$ by vol) of $\mathrm{H}_{2} \mathrm{SO}_{4}$ and $\mathrm{NaOH}$ (10\% by wt) at temperature 50 and $100{ }^{\circ} \mathrm{C}$ for the period of 30, 60 and $90 \mathrm{~min}$. For each experiment, the coal to the solution was taken 1:10 ratio. After a studied range of time and temperature, it is filtered and washed with distilled water. The aqueous coal slurry filtered by using Whatman filter paper and then dried in hot air oven at $90{ }^{\circ} \mathrm{C}$ for 2-3 h. The treated coal was done for ash analysis for calculating the percent demineralization.

The leaching time in this paper is defined as the time passed after the reaction mixture has reached the defined reaction temperature and we assume all the mineral in coal are formed ash after combustion. The percent of demineralization is defined in the following Eq. (1).

Percent demineralization $=\left(\frac{\text { ash content in raw coal }- \text { ash content in treated coal }}{\text { ash content in raw coal }} \times 100\right)$ 


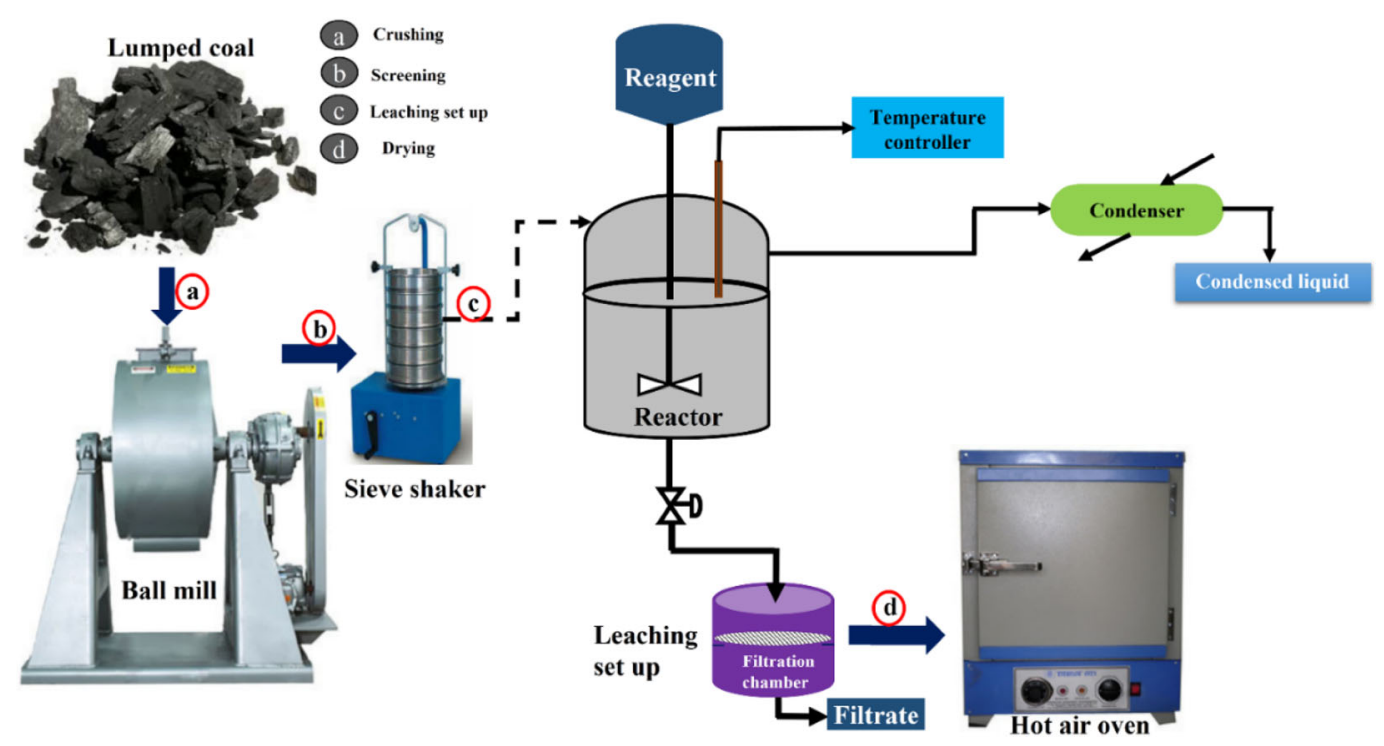

Fig. 1 Comminution of lumped coal and the experimental setup for leaching process

The yield of clean coal is defined as the mass ratio of clean coal recovered after treatment to feed coal, both on dry ash free basis. The Eq. (2) used for coal yield as follows

Coal yield $=\left(\frac{m_{2}}{m_{1}}\right) \times 100$

where $m_{1}$ and $m_{2}$ mass of raw and leached dry coal sample (g).

\section{Results and discussion}

\subsection{Effect of concentration on coal demineralization}

The alkali and acid solution were a direct effect on demineralization of coal in contrast to alone effect of the deionized water. The demineralization of coal by using deionized water was found less effect as compared to acid and alkali leaching for removal of mineral matter from the coal matrix. It has been found from the experimental results up to $11 \%$ and $12 \%$ demineralization were obtained from coal A and coal B by the effect of deionized water. It may be the major mineral constituents of the raw coals were not dissolute during the leaching process. It has been seen from Fig. 2 the percent demineralization was increased with the rise of alkali $(\mathrm{NaOH})$ and sulfuric acid $\left(\mathrm{H}_{2} \mathrm{SO}_{4}\right)$ concentration with in treated coal. It has been found from the investigation the most efficient demineralization were obtained from coal A and coal B of $180 \mu \mathrm{m}$ particle size. The degree of demineralization was obtained to $46 \%$ and $34 \%$ from coal A consists of $38.8 \%$ ash. Similarly the results obtained for coal B were $43 \%$ and $32 \%$ from $43 \%$ ash by the effect of $30 \% \mathrm{NaOH}$ and $30 \%$ $\mathrm{H}_{2} \mathrm{SO}_{4}$ solvent concentration respectively. It has been found from the investigation; the caustic-treated coal was found greater percent demineralization as compared to acid treated coal. Naturally, the Indian coal incorporates with large quantity minerals such as alumina, quartz, pyrites, and carbonates out of which $85 \%-90 \%$ minerals generally alumina and silica content (Kumar and Shankar 2000). Generally, the alumina and silica are present in the separate entity or in the mixed form of aluminosilicate compounds, such as kaolinite $\left(\mathrm{Al}_{2} \mathrm{Si}_{2} \mathrm{O}_{5}(\mathrm{OH})_{4}\right)$, and clays (like (NaMg,Al) $\left.\mathrm{Si}_{4} \mathrm{O}_{10}(\mathrm{OH})_{2}\right)$. The mechanism for leaching process was occurred by the chemical reagents (alkali or acid) were diffused from the outer surface of the coal matrix and enters through the pores to inner side coal of the core. The silica, alumina and other clay bearing minerals were easily dissolute during the diffusion of an alkali solution and formed the soluble sodium silicate, sodium aluminate and sodium-aluminosilicates compounds (Kumar and Gupta 1997).

The larger quantity dissolution of the inorganic minerals by the caustic effect may be due to the high affinity of hydroxyl $\mathrm{OH}^{-}$(hydroxyl ion) towards the mineral in the coal matrix (Behera et al. 2017a, b). The residual minerals were displaced by the effect of an alkali solution and trapped inside pore of the coal matrix. But during acid 

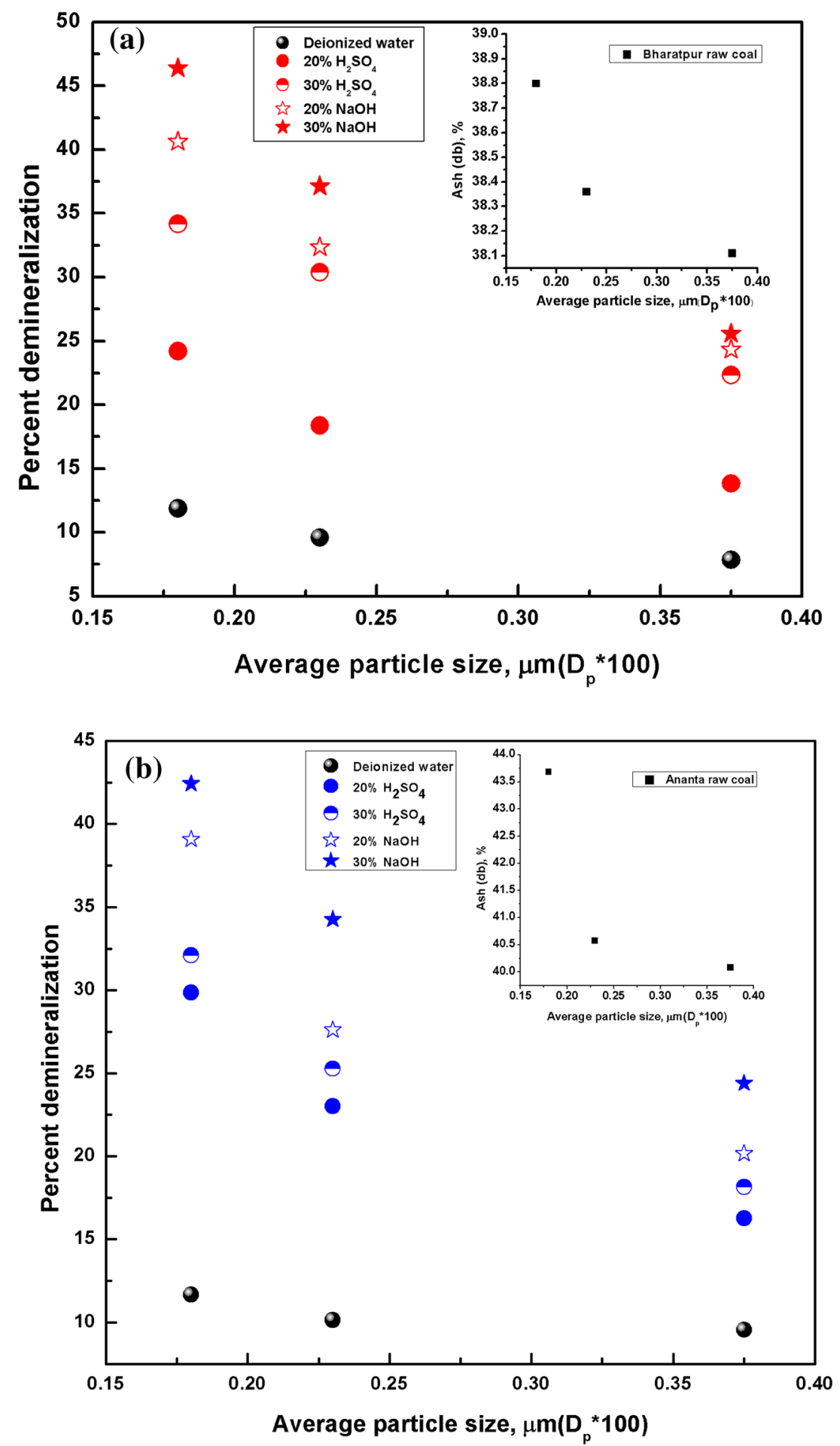

Fig. 2 Effect of the reagent concentration and particle size on the percent demineralization of a coal A and $\mathbf{b}$ coal B

leaching, the major mineral like silica and alumina components were less soluble. However, pyrite $\left(\mathrm{FeS}_{2}\right)$, calcite $\left(\mathrm{CaCO}_{3}\right)$, and hematite $\left(\mathrm{Fe}_{2} \mathrm{O}_{3}\right)$ and other mineral constituents were easily dissolute and formed soluble compounds of calcium sulphate $\left(\mathrm{CaSO}_{4}\right)$ and $\mathrm{Fe}_{2}\left(\mathrm{SO}_{4}\right)_{3}$. The following possible reactions were shown for alkali in
Eqs. (3), (4) and (5) and for acid leaching in Eq. (6). The leaching mechanism for the demineralization of coal was shown in Fig. 3.

$2 \mathrm{NaOH}+\mathrm{SiO}_{2} \rightarrow \mathrm{Na}_{2} \mathrm{SiO}_{3}+\mathrm{H}_{2} \mathrm{O}$ 


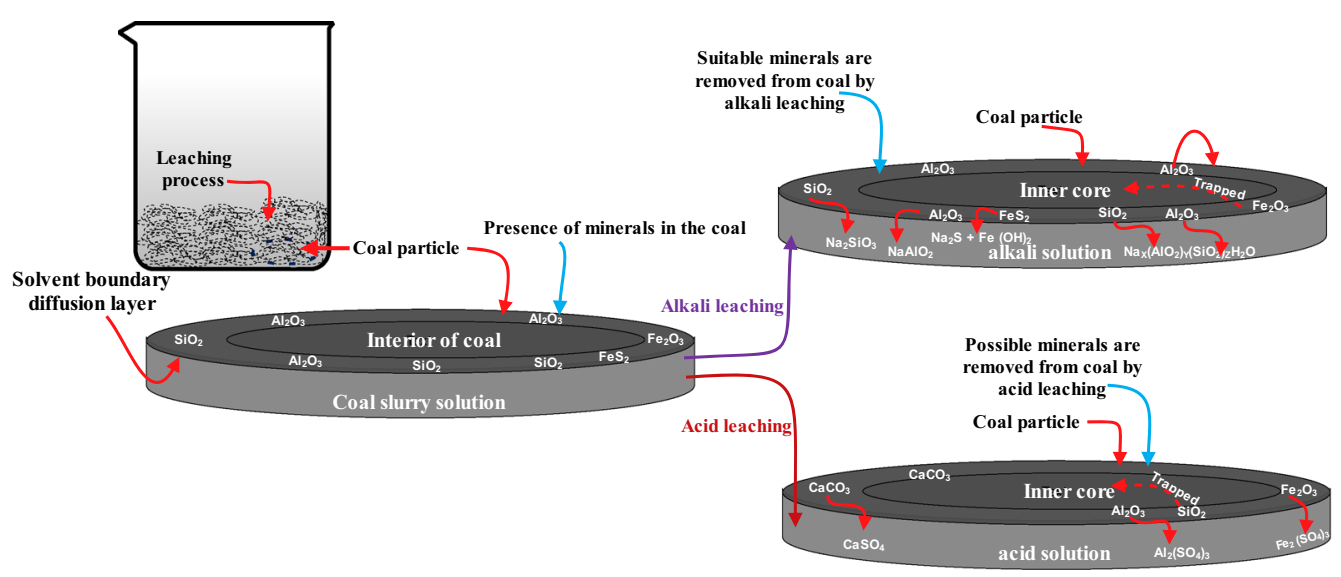

Fig. 3 Mechanism of dissolution of minerals in the leaching process

$$
\begin{aligned}
& 2 \mathrm{NaOH}+\mathrm{Al}_{2} \mathrm{O}_{3} \rightarrow 2 \mathrm{NaAlO}_{2}+\mathrm{H}_{2} \mathrm{O} \\
& \mathrm{NaOH}_{(\mathrm{aq})}+\mathrm{NaAlO}_{2(\mathrm{aq})}+\mathrm{Na}_{2} \mathrm{SiO}_{3(\text { aq })} \\
& \rightarrow \mathrm{Na}_{\mathrm{X}}\left(\mathrm{AlO}_{2}\right)_{\mathrm{Y}}\left(\mathrm{SiO}_{2}\right)_{\mathrm{Z}} \mathrm{NaOH}^{\mathrm{N}} \mathrm{H}_{2} \mathrm{O} \\
& \mathrm{Fe}_{2} \mathrm{O}_{3}+3 \mathrm{H}_{2} \mathrm{SO}_{4} \rightarrow \mathrm{Fe}_{2}\left(\mathrm{SO}_{4}\right)_{3}+3 \mathrm{H}_{2} \mathrm{O}
\end{aligned}
$$

\subsection{Effect of particle size on demineralization of coal}

The size of coal particle affects the effectiveness of the chemical cleaning process. The effect of particle size on the percent demineralization of coal was depicted in Fig. 2. The ash content of the raw coal varies with the particle size. The extent of demineralization increases with the decrease of particle size. In the present investigation, $180 \mu \mathrm{m}$ coal particle has been found maximum percent demineralization as compared to 375 and $230 \mu \mathrm{m}$ mesh size particle. This may be due to the finer size particle were contains large surface area leads to increase the demineralization. The ash content of raw coals were decreased with increase in particle size while these were increased in the leached coal. Therefore, the percent demineralization were increased with decrease size of particles. From the experimental results, the finer $(180 \mu \mathrm{m})$ particle size were obtained highest percent demineralization, about $46 \%$ and $34 \%$ from coal A, $42 \%$ and $32 \%$ from coal B by the leaching solvent concentration of $30 \% \mathrm{NaOH}$ and $30 \%$ $\mathrm{H}_{2} \mathrm{SO}_{4}$ solution respectively. The decreased size of the particles caused higher the exposed surface area, which enhances the interaction between the leachant and coalbearing minerals. This may because the ash-bearing minerals were easily dissolute in the chemical solvent. The dissolution of minerals were more accessible for finer size particles which may the less diffusion gap, and more contact between the finer size particles and the leachant caused the higher rate of minerals were leached out.

\subsection{Effect of temperature}

The temperature is one of the most effective parameters in the leaching process. As from Table 3, the extent of demineralization was increased because of the increase reaction temperature during the experiment by increasing thermal energy which results in the enhanced the rate of reaction of leaching. In this case, the greater extent of demineralization were obtained at a high temperature $\left(100{ }^{\circ} \mathrm{C}\right)$ about $32.40 \%$, and $17.11 \%$ from coal $\mathrm{A}$ also obtained $28.39 \%$ and $23.17 \%$ from coal B by treated with $10 \% \mathrm{NaOH}$ and $10 \% \mathrm{H}_{2} \mathrm{SO}_{4}$ solution respectively. The heating effect caused the increased the activation energy of reaction that facilitated easier to detached the bonding force between the mineral and coal in the coal matrix. Temperature is also affecting the yield of coal. At high temperature, the yield of coals were decreased for finer particles due to the greater extent of degree of demineralization.

\subsection{Effect of time}

The time factor was the most crucial role during the leaching process because it decides the contact between mineral phases in the coal and the leachant. It has been found from the Table 3, the percent demineralization was increased with time. The reason behind for higher demineralization may be due to the greater the contact time between the minerals of coal and the leachants, which caused the increased the liberation of minerals in the leaching process.

The characterization of coal was studied only at maximum percent-demineralized coal particle size. These studies of coal sample signified to evaluate the performance of the percent demineralization. 
Table 3 Leaching parameter effects on the coal A and coal B

\begin{tabular}{|c|c|c|c|c|c|c|c|}
\hline \multirow{2}{*}{$\begin{array}{l}\text { Coal type and } \\
\text { particle size }(\mu \mathrm{m})\end{array}$} & \multirow{2}{*}{$\begin{array}{l}\text { Raw coal } \\
\text { ash }(\%)\end{array}$} & \multirow{2}{*}{$\begin{array}{l}\text { Temperature } \\
\left({ }^{\circ} \mathrm{C}\right)\end{array}$} & \multirow[t]{2}{*}{ Time $(\min )$} & \multicolumn{2}{|c|}{ Percent demineralization } & \multicolumn{2}{|c|}{ Coal yield (\%) } \\
\hline & & & & $10 \% \mathrm{NaOH}$ & $10 \% \mathrm{H}_{2} \mathrm{SO}_{4}$ & $10 \% \mathrm{NaOH}$ & $10 \% \mathrm{H}_{2} \mathrm{SO}_{4}$ \\
\hline \multicolumn{8}{|l|}{ Coal A } \\
\hline \multirow[t]{6}{*}{230} & \multirow[t]{6}{*}{38.36} & \multirow[t]{3}{*}{50} & 30 & 11.37 & 6.41 & 90.53 & 94.84 \\
\hline & & & 60 & 13.45 & 8.50 & 90.21 & 94.2 \\
\hline & & & 90 & 15.28 & 11.11 & 90.5 & 94 \\
\hline & & \multirow[t]{3}{*}{100} & 30 & 17.10 & 9.54 & 91.2 & 94.1 \\
\hline & & & 60 & 21.53 & 10.84 & 90.4 & 94.06 \\
\hline & & & 90 & 28.52 & 13.43 & 89.72 & 93.46 \\
\hline \multirow[t]{6}{*}{180} & \multirow[t]{6}{*}{38.80} & \multirow[t]{3}{*}{50} & 30 & 14.43 & 8.76 & 87.26 & 92.21 \\
\hline & & & 60 & 15.98 & 9.02 & 86.26 & 91.5 \\
\hline & & & 90 & 17.53 & 12.11 & 85.5 & 90.31 \\
\hline & & \multirow[t]{3}{*}{100} & 30 & 14.95 & 12.89 & 84.11 & 89.02 \\
\hline & & & 60 & 15.98 & 14.69 & 84.34 & 88.33 \\
\hline & & & 90 & 32.40 & 17.11 & 83.9 & 87.29 \\
\hline \multicolumn{8}{|l|}{ Coal B } \\
\hline \multirow[t]{6}{*}{230} & \multirow[t]{6}{*}{40.57} & \multirow[t]{3}{*}{50} & 30 & 1.65 & 4.61 & 94.1 & 96.78 \\
\hline & & & 60 & 4.12 & 6.83 & 93.5 & 96.22 \\
\hline & & & 90 & 7.07 & 7.07 & 93.12 & 95.56 \\
\hline & & \multirow[t]{3}{*}{100} & 30 & 12.50 & 8.80 & 94.7 & 95.12 \\
\hline & & & 60 & 13.73 & 10.77 & 95.2 & 94.78 \\
\hline & & & 90 & 20.16 & 13.31 & 93.4 & 93.55 \\
\hline \multirow[t]{6}{*}{180} & \multirow[t]{6}{*}{43.68} & \multirow[t]{3}{*}{50} & 30 & 10.26 & 11.40 & 86.52 & 94.44 \\
\hline & & & 60 & 13.92 & 14.61 & 85.31 & 94.21 \\
\hline & & & 90 & 15.06 & 15.52 & 84.2 & 93.34 \\
\hline & & \multirow[t]{3}{*}{100} & 30 & 22.16 & 19.35 & 83.4 & 90.32 \\
\hline & & & 60 & 25.60 & 21.02 & 83.43 & 88.24 \\
\hline & & & 90 & 28.39 & 23.17 & 82.33 & 86.34 \\
\hline
\end{tabular}

Table 4 Ash analysis results of coal samples

\begin{tabular}{|c|c|c|c|c|c|c|c|c|}
\hline \multirow[t]{2}{*}{ Mineral oxide } & \multicolumn{4}{|l|}{ Coal A } & \multicolumn{4}{|l|}{ Coal B } \\
\hline & Raw coal & $30 \% \mathrm{NaOH}$ & $40 \% \mathrm{NaOH}$ & $30 \% \mathrm{H}_{2} \mathrm{SO}_{4}$ & Raw coal & $30 \% \mathrm{NaOH}$ & $40 \% \mathrm{NaOH}$ & $30 \% \mathrm{H}_{2} \mathrm{SO}_{4}$ \\
\hline $\mathrm{Na}_{2} \mathrm{O}$ & 0.22 & 6.81 & 13.21 & 0.15 & 0.116 & 9.462 & 19.62 & 0.103 \\
\hline $\mathrm{MgO}$ & 0.59 & 0.46 & 0.35 & 0.89 & 0.411 & 0.423 & 0.19 & 0.705 \\
\hline $\mathrm{Al}_{2} \mathrm{O}_{3}$ & 22.56 & 12.76 & 11.25 & 17.42 & 22.41 & 14.63 & 11.52 & 20.39 \\
\hline $\mathrm{SiO}_{2}$ & 46.89 & 27.33 & 24.35 & 50.40 & 40.56 & 22.51 & 20.26 & 47.22 \\
\hline $\mathrm{P}_{2} \mathrm{O}_{5}$ & 0.18 & 0.107 & 0.11 & 0.073 & 0.482 & 0.42 & 0.31 & 0.156 \\
\hline $\mathrm{SO}_{3}$ & 0.30 & 1.575 & 1.79 & 0.553 & 0.133 & 2.45 & 3.17 & 0.157 \\
\hline $\mathrm{K}_{2} \mathrm{O}$ & 0.62 & 0.698 & 0.949 & 0.49 & 0.567 & 0.558 & 0.835 & 0.78 \\
\hline $\mathrm{CaO}$ & 0.45 & 0.736 & 0.89 & 0.181 & 0.602 & 0.793 & 0.982 & 0.138 \\
\hline $\mathrm{Fe}_{2} \mathrm{O}_{3}$ & 2.32 & 2.796 & 3.52 & 0.856 & 2.407 & 2.768 & 4.26 & 0.516 \\
\hline
\end{tabular}


Table 5 Trace element concentration (ppm) in coal sample by XRF analysis

\begin{tabular}{|c|c|c|c|c|c|c|}
\hline \multirow[t]{2}{*}{ Elements } & \multicolumn{3}{|l|}{ Coal A } & \multicolumn{3}{|l|}{ Coal B } \\
\hline & Raw coal & $30 \% \mathrm{NaOH}$ & $30 \% \mathrm{H}_{2} \mathrm{SO}_{4}$ & Raw coal & $30 \% \mathrm{NaOH}$ & $30 \% \mathrm{H}_{2} \mathrm{SO}_{4}$ \\
\hline $\mathrm{Ti}$ & 6640 & 7530 & 7300 & 7130 & 8290 & 8800 \\
\hline V & 120 & - & - & 170 & 70 & 190 \\
\hline $\mathrm{Cr}$ & 200 & 150 & 160 & 160 & 150 & 190 \\
\hline Mn & 90 & 100 & 100 & 140 & 150 & 70 \\
\hline Co & - & - & 100 & - & - & 160 \\
\hline $\mathrm{Ni}$ & 50 & 70 & 70 & 60 & 60 & 30 \\
\hline $\mathrm{Cu}$ & 1070 & 2220 & 1320 & 1020 & 120 & 1270 \\
\hline $\mathrm{Zn}$ & 250 & 140 & 590 & 50 & 120 & 750 \\
\hline $\mathrm{Ga}$ & - & 30 & - & - & - & 40 \\
\hline $\mathrm{Rb}$ & - & 50 & 40 & 250 & - & 30 \\
\hline $\mathrm{Sr}$ & 70 & 50 & 50 & 110 & 120 & 90 \\
\hline $\mathrm{Y}$ & 140 & 40 & - & - & 50 & 30 \\
\hline $\mathrm{Zr}$ & 250 & 290 & 280 & 410 & 540 & 320 \\
\hline $\mathrm{Nb}$ & - & 30 & 30 & 130 & 20 & 20 \\
\hline Sn & - & 120 & 150 & - & 220 & 310 \\
\hline $\mathrm{Ba}$ & - & 110 & 150 & - & - & 100 \\
\hline $\mathrm{La}$ & - & - & - & - & - & 160 \\
\hline $\mathrm{Ce}$ & - & - & - & - & 420 & 190 \\
\hline $\mathrm{Pb}$ & - & - & 200 & - & 420 & - \\
\hline $\mathrm{Cl}$ & 90 & - & - & - & - & - \\
\hline Mo & - & - & 50 & - & - & - \\
\hline $\mathrm{Rh}$ & - & - & 90 & - & - & - \\
\hline $\mathrm{Hg}$ & 120 & - & - & - & - & - \\
\hline $\mathrm{Au}$ & 920 & - & 720 & - & - & - \\
\hline $\operatorname{Pr}$ & 90 & - & - & - & - & - \\
\hline $\mathrm{Cr}$ & 200 & - & - & - & - & - \\
\hline
\end{tabular}

\subsubsection{Ash analysis of coal}

The composition of mineral oxides and the trace element concentration for pre and post-treated coal were evaluated in XRF analysis and the results were summarized in Tables 4 and 5. It has been observed from Table 4, the composition of mineral oxides $\left(\mathrm{Fe}_{2} \mathrm{O}_{3}, \mathrm{Na}_{2} \mathrm{O}, \mathrm{CaO}\right.$ contents of the raw coal were increased in alkali treated coal, however, these oxides were easily dissolute during acid leaching. The increased minerals caused due to the insoluble during the caustic treatment. The major minerals like $\mathrm{SiO}_{2}$ (quartz), $\mathrm{Al}_{2} \mathrm{O}_{3}$ (alumina) contents of raw coal were decreased in the alkali treated coal while, in case of acidic treatment these minerals of raw coal (silica, alumina and other clay bearing) were insoluble but alumina of the raw coal slightly soluble during acid leaching. Therefore, the composition of insoluble mineral contents was higher during acidic treatment, and some minerals were drastic changes in contrast to raw coal. The mineral in the coal are heterogeneous in nature and it is unevenly distributed in the coal matrix. It has been observed from XRF analysis, the major minerals of the raw coal (especially silica and alumina) has been removed up to $40 \%$ above by the alkali treatment. The effect of alkali leaching at a higher concentration on coal A and coal B for the comparison of better demineralization were shown in Table 4 . It has been observed from results the extent of demineralization was increased by the effect of $40 \% \mathrm{NaOH}$ concentration. The observation showed that Coal B was leached out above $50 \%$ silica and alumina minerals than coal A and the basic compounds were increased in both the leached coal.

Similarly, the trace elements are also responsible for the formation of ash in the coal. The trace elements are in the coal ash formed due to its natural formation process of the parent coal. Most of the trace elements in the parent coal are retained in the residual coal ash after combustion and are concentrated in a small volume of the ash compared to raw coal. Therefore, the trace elements in the coal ash are 
Table 6 Calorific value of coals

\begin{tabular}{llll}
\hline Coal type & \multicolumn{2}{l}{ Calorific value $(\mathrm{kcal} / \mathrm{kg})$} \\
\cline { 2 - 4 } & Raw coal & Alkali leached coal & Acid leached coal \\
\hline Coal A & 4789.5 & 5979.7 & 5127.5 \\
Coal B & 4586.3 & 5789.3 & 5651.3 \\
\hline
\end{tabular}

higher compared to the parent coal (Carlson and Adriano 1993; Jankowski et al. 2006; Miej 1994). Major mineral constituents of coal ash typically consist of silicon ( $\mathrm{Si})$, aluminum $(\mathrm{Al})$, and iron $(\mathrm{Fe})$, with lesser amounts of oxides of calcium $(\mathrm{Ca})$, magnesium $(\mathrm{Mg})$, potassium $(\mathrm{K})$, sulfur $(\mathrm{S})$, and phosphorus $(\mathrm{P})$ whose proportions changes with the leaching effect. Coal ash also contains minor amounts of trace elements, including titanium (Ti), chromium (Cr), nickel $(\mathrm{Ni})$, zinc $(\mathrm{Zn})$, arsenic (As), selenium $(\mathrm{Se})$, cadmium $(\mathrm{Cd})$, antimony $(\mathrm{Sb})$, mercury $(\mathrm{Hg})$, and lead $(\mathrm{Pb})$, vanadium $(\mathrm{V})$, copper $(\mathrm{Cu})$, Manganese $(\mathrm{Mn})$, Cobalt (Co), Yttrium (Y), Zirconium (Zr) etc. The degree of ash content depends on the concentration of trace elements as well as major mineral constituents in the coal. The leaching studies indicated trace elements were removed by the influence of leaching effect. It has been observed from Table 5, the trace elements titanium (Ti) was increased by the leaching effect as compared to the raw coal while most of the trace elements were removed by the chemical treatment. The effective separation of the specific element corresponding to the minerals depend on the type of chemical reagent was used. It has been found from XRF analysis, a major amount of ash-bearing minerals from the coal were leached out during the caustic effect.

\subsubsection{Calorific value}

The calorific value of coal was determined by high-pressure oxygen Bomb calorimeter (LECO AC 500). The calorific value of coal depends on the extent of demineralization. Table 6 shows the heating value or calorific value of raw coal as well as treated coal samples at maximized demineralization stage. The results explained that the calorific value of treated coal has been increased with the extent of demineralization. The calorific value of coals were increased from original coal sample by $20 \%$ and $21 \%$ for $10 \mathrm{wt} \% \mathrm{NaOH}$ treated coal and increased to $7 \%$ and $19 \%$ for 10 vol. $\% \mathrm{H}_{2} \mathrm{SO}_{4}$ treated coal of coal A and coal B respectively. The alkali leached coal has been found higher the calorific value in comparison to acid treated coal. The reason might be the alkali removed most of the non-carbonaceous mineral matter which have no heating value and which have higher percent demineralization (Ishaq et al. 2002). The higher is the calorific value signifies the better the quality of the coal.

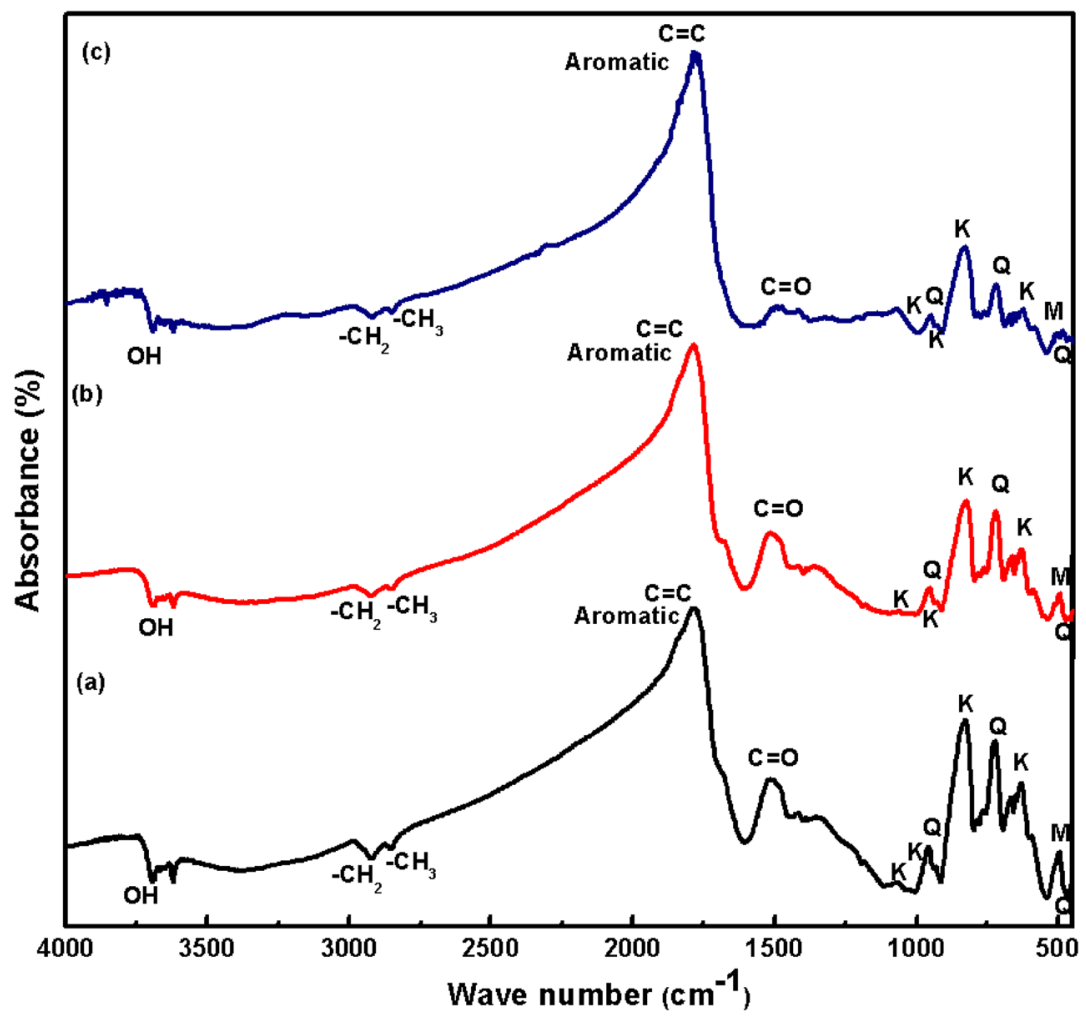

Fig. 4 FTIR pattern of coal A for (a) raw coal, (b) $30 \% \mathrm{H}_{2} \mathrm{SO}_{4}$ and (c) $30 \% \mathrm{NaOH}$ solution 


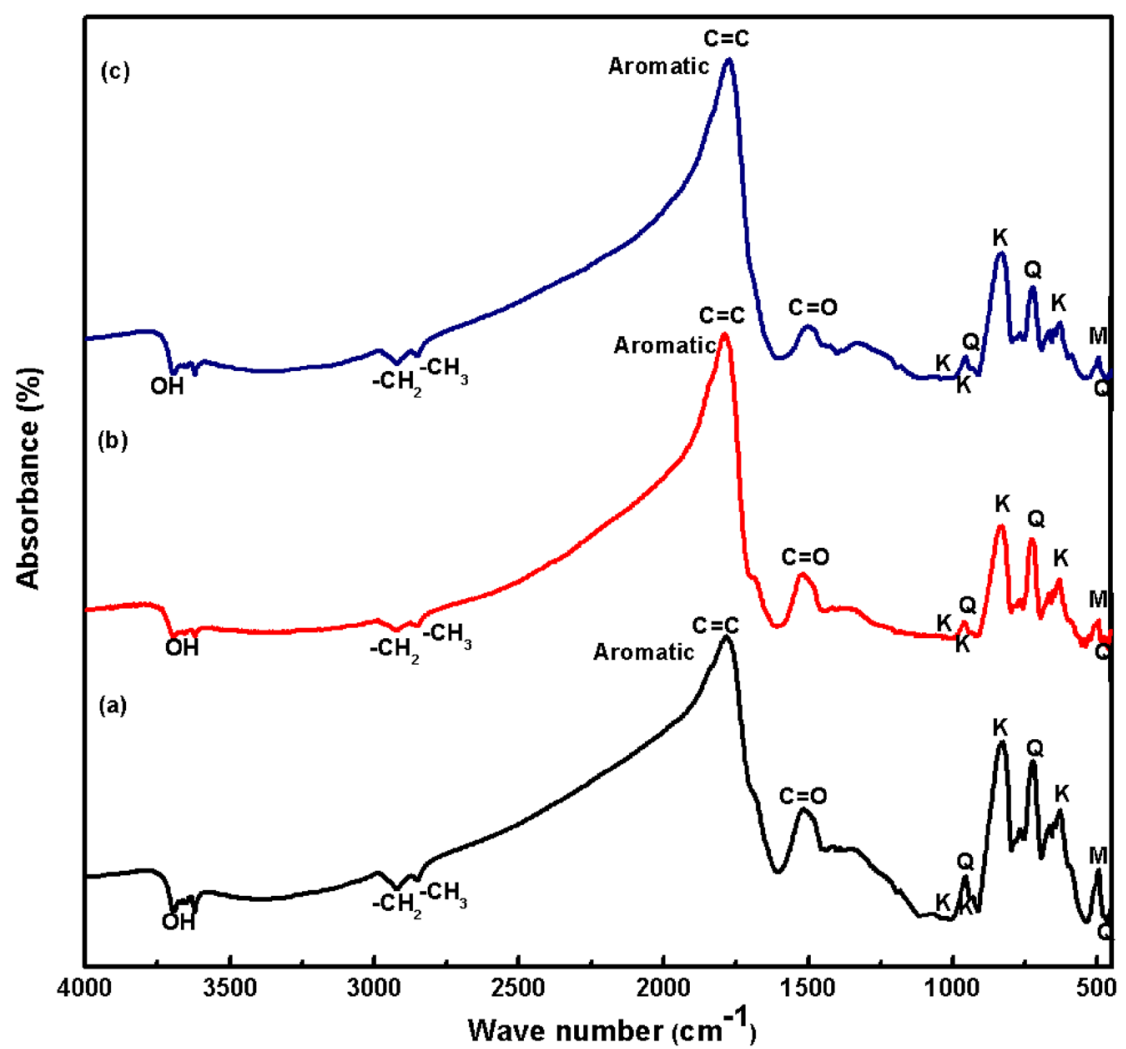

Fig. 5 FTIR pattern of coal B for (a) raw coal, (b) $30 \% \mathrm{H}_{2} \mathrm{SO}_{4}$ and (c) $30 \% \mathrm{NaOH}$ solution. (Notation: M- Montmorillonite, K-kaolinite, Q-quartz)

\subsubsection{FTIR analysis}

In the FTIR analysis, the respective transmittance value at particular wavelength signifies the presence of the functional groups. The measuring region within the range from 4000 to $450 \mathrm{~cm}^{-1}$ wave number (Ge et al. 2013). In Figs. $4 \mathrm{a}-\mathrm{c}$ and $5 \mathrm{a}-\mathrm{c}$ shows the FTIR spectra absorption bands of the original and treated samples with $\mathrm{H}_{2} \mathrm{SO}_{4}$ and $\mathrm{NaOH}$ of coal A and coal B respectively. In FTIR spectra, most of the absorption band peaks in between 450 and $1100 \mathrm{~cm}^{-1}$ of coal can be assigned to clay minerals such as quartz $(\mathrm{Q})$, kaolinite $(\mathrm{K})$, illite and montmorillonite (M) groups (Dash et al. 2015a, b; Behera et al. 2018). Therefore these peaks are called the mineral band. The distinct peaks at 1008 and $1031 \mathrm{~cm}^{-1}$ are for kaolinite mineral group and $471 \mathrm{~cm}^{-1}$ can be attributed to quartz in the coal samples. The peaks correspond to the mineral band for the leached coal gradually decreased by the leaching effect of acid and alkali reagents as compared to raw coal. This may be due to the removal of hydroxyl groups of aluminosilicates in the coal. From Figs. 4 and 5, the variation of the peak intensity of raw and leached coal revealed that liberation of minerals by the leaching effect. Peak in between 1650 and $1870 \mathrm{~cm}^{-1}$ corresponding to carbonyl compound, peak at $1630-1680 \mathrm{~cm}^{-1}$ relate to $\mathrm{C}=\mathrm{C}, 2850$ and $2920 \mathrm{~cm}^{-1}$ corresponding to $\mathrm{CH}_{2}$ and $\mathrm{CH}_{3}$ groups. The peaks at above $3000 \mathrm{~cm}^{-1}$ related to the presence of the $\mathrm{OH}$ group. However, it is very difficult to the identification of the infrared absorption bands for the spectra of silicates and aluminate and other clay minerals in the coal because of their complicated and variable composition with isomorphous substitutions of band positions.

\subsubsection{SEM morphology and elementary analysis}

The surface morphology and elementary composition of the mineral group in the raw coal and leached coal was studied. The SEM micrograph and the EDS analysis of raw and leached sample were provided in Fig. 6 and Table 7. The EDX analysis study found that majority of the minerals were removed by the leaching effect and increased the carbon content of the leached coal. Figure 6a, $d$ represents the SEM micrograph of the original coal A and coal B contains large amount silica, alumina, hematite minerals and the lesser percentage of carbon content as well as the small proportion of elements such as calcium, potassium, sulfur, etc. The SEM micrograph Fig. 6b, c, e, f of coal A and coal $\mathrm{B}$ revealed that the carbon content of the original coal has been improved with the percent demineralization. The carbon content of both raw coal were increased from 

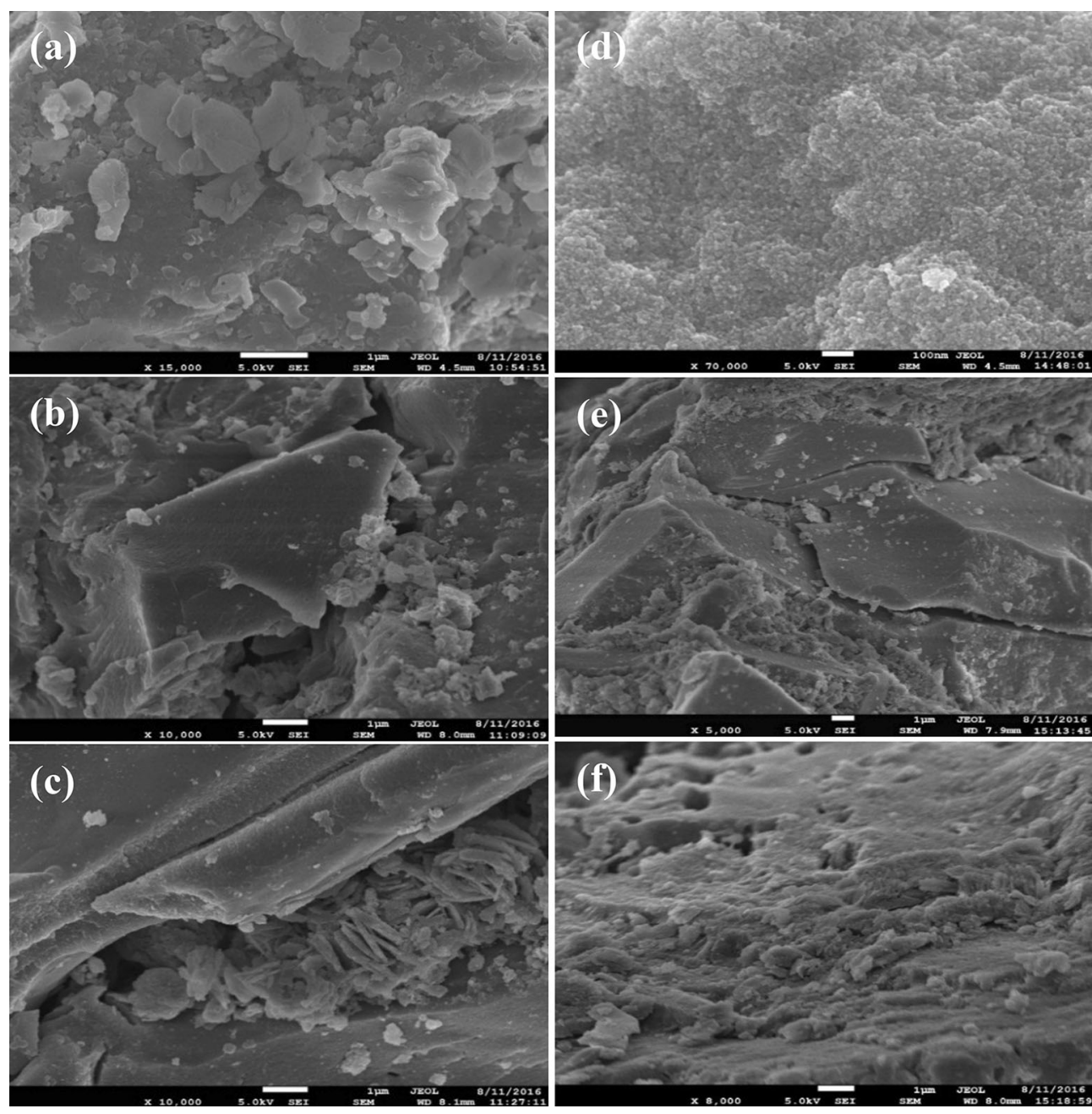

Fig. 6 SEM micrograph of a raw coal, b $30 \% \mathrm{NaOH}$ and c $30 \% \mathrm{H}_{2} \mathrm{SO}_{4}$ for coal A and coal B respectively

Table 7 EDS analysis of coal samples

\begin{tabular}{|c|c|c|c|c|c|c|}
\hline \multirow[t]{2}{*}{ Elements } & \multicolumn{3}{|l|}{ Coal A } & \multicolumn{3}{|l|}{ Coal B } \\
\hline & Raw coal & $30 \% \mathrm{NaOH}$ & $30 \% \mathrm{H}_{2} \mathrm{SO}_{4}$ & Raw coal & $30 \% \mathrm{NaOH}$ & $30 \% \mathrm{H}_{2} \mathrm{SO}_{4}$ \\
\hline $\mathrm{C}$ & 46.03 & 75.24 & 68.82 & 44.56 & 73.22 & 67.46 \\
\hline $\mathrm{O}$ & 36.4 & 15.66 & 17.62 & 36.48 & 16.65 & 18.5 \\
\hline $\mathrm{Na}$ & 0.65 & 0.81 & 0.22 & 0.85 & 0.91 & 0.31 \\
\hline $\mathrm{Si}$ & 8.49 & 2.35 & 6.32 & 9.86 & 3.43 & 7.65 \\
\hline $\mathrm{Al}$ & 5.88 & 2.93 & 5.26 & 5.96 & 2.68 & 4.31 \\
\hline S & 0.91 & 0.67 & 1.11 & 0.67 & 1.05 & 0.95 \\
\hline $\mathrm{K}$ & 0.15 & 0.46 & 0.13 & 0.28 & 0.37 & 0.13 \\
\hline $\mathrm{Ca}$ & 0.52 & 0.2 & 0.13 & 0.67 & 0.52 & 0.33 \\
\hline $\mathrm{Fe}$ & 0.97 & 1.68 & 0.39 & 0.67 & 1.17 & 0.36 \\
\hline
\end{tabular}

$44 \%$ to $75 \%$ and $68 \%$ by the effect of alkali and acid leaching. The increase in carbon content of original coal by the leaching effect may be due to the reaction of the chemical solvents to the concealed minerals and the dissolution of the ash-bearing mineral constituents in the coal matrix. It also noticed that the liberation of mineral contents were drastically changed and the 'Fe' content increased in the caustic-treated coal. The liberation of ' $\mathrm{Fe}$ ' 
content was increased from the pyrite and hematite group of minerals during the leaching process. The maximum amount of silica (quartz), alumina and minerals associated with clay particles were leached out during alkali leaching. The reason may be due to the high affinity of $\mathrm{OH}^{-}$(hydroxyl ions) towards the silica and alumina minerals of the raw coal. The SEM micrograph Fig. 6e, f of coal A and coal $\mathrm{B}$ revealed that the percentage silica, alumina, and clay-bearing minerals were increased in the $\mathrm{H}_{2} \mathrm{SO}_{4}$ leaching. These minerals were insoluble during acid leaching. It can be observed in Fig. 6, the chemical solvents were enormous harm to the coal surface during the process of leaching and voids has been produced on the coal surface, which signifies that minerals were liberated by the leaching effect.

However, the surface layer of the SEM images were still observed bright and luminous, that indicate may be the presence of mineral species.

\section{Conclusions}

It has been concluded from the investigation, the better generation of clean coal was obtained by the leaching process when the process conditions were properly selected. The result outcomes from the present research may justify that it is a convenient process for chemical cleaning of low grade coal at moderate leaching conditions. The extent of demineralization depends on the increase the solvent concentration, temperature, leaching time and decreasing the size of the particles. The maximum mineral matter was removed from Bharatpur (coal A) and Ananta (coal B) by alkali leaching and the acid fluxing agent. The highest degree of demineralization has been obtained from raw coal ash of $38.8 \%$ to $46 \%$ and $34 \%$ of coal A, similar from $43 \%$ to $42 \%$ and $32 \%$ of coal B by the solvent concentration of $30 \% \quad \mathrm{NaOH}$ and $30 \% \quad \mathrm{H}_{2} \mathrm{SO}_{4}$ solution respectively. The percent demineralization of coal was greater by the caustic soda $(\mathrm{NaOH})$ treatment as compared to acid treated coal. From the investigation, it has been found that the alkali concentration was more efficient for demineralization of coal. The fine particle size was the great effect on demineralization process as compared to the larger size of coal particle. However, the yield of clean coal for the finer particle was less while more in the case of the larger size of coal particle. The ash percent of the raw coal was decreased with increasing the size of coal particles, but it increased with increasing size of leached coal particle size. The calorific value of leached coal was increased with the percent demineralization. It has been observed that from the XRF results that most of the inorganic elements has been reduced by the effect of alkali leaching and less in acid treatment. The FTIR results indicate lower the peak intensity of the mineral bands for the demineralized coal. The SEM-EDX results showed that the carbon content of the original coal has been increased from $44 \%$ to $75 \%$ and $40 \%$ above the major mineral constituents has been removed from the original coal sample, which signified improvement coal rank, and changes the quality of coal.

Acknowledgements The authors would like to acknowledge the Indian Institute of Technology Kharagpur for help and support during the research period. The authors very much thankful to the reviewers for suggesting valuable technical comments of this paper.

Open Access This article is distributed under the terms of the Creative Commons Attribution 4.0 International License (http://crea tivecommons.org/licenses/by/4.0/), which permits unrestricted use, distribution, and reproduction in any medium, provided you give appropriate credit to the original author(s) and the source, provide a link to the Creative Commons license, and indicate if changes were made.

\section{References}

Adeleke AA, Ibitoye SA, Afonja AA, Chagga MM (2011) Multistage caustic leaching de-ashing of Nigerian Lafia-Obi coal. Pet Coal 53(4):259-265

ASTM Standard D3173-11 (2011) Standard test method for moisture in the analysis sample of coal and coke. ASTM International, West Conshohocken

ASTM Standard D3174-11 (2011) Standard test method for ash in the analysis sample of coal and coke from coal. ASTM International, West Conshohocken

ASTM Standard D3175-11 (2011) Standard test method for volatile matter in the analysis sample of coal and coke. ASTM International, West Conshohocken

Behera SK, Chakraborty S, Meikap BC (2017a) Chemical demineralization of high ash Indian coal by using alkali and acid solutions. Fuel 196:102-109

Behera SK, Chakraborty S, Meikap BC (2017b) Up-gradation of low grade coal to high-quality coal by chemical beneficiation technique. In: ASME. ASME conference proceeding, vol 1: fuels, combustion and material handling, p V001T04A006. https://doi.org/10.1115/power-icope2017-3057

Behera SK, Chakraborty S, Meikap BC (2018) Removal of ash from low grade Indian coal by chemical leaching technique. Miner Process Extr Metall Rev 39(1):59-67

Bolat E, Saglam S, Piskin S (1998) Chemical demineralization of a Turkish high ash bituminous coal. Fuel Process Technol 57(2):93-99

Carlson CL, Adriano DC (1993) Environmental impacts of coal combustion residues. J Environ Qual 22(2):227-247

Choudhury R, Bhaktavatsalam AK (1997) Beneficiation of Indian coal by chemical techniques. Energy Convers Manag 38(2):173-178

Ciu L, Guo Y, Wang X, Du Z, Cheng F (2015) Dissolution kinetics of aluminum and iron from coal mining waste by hydrochloric acid. Chin J Chem Eng 23(3):590-596

Culfaz M, Ahmed M, Gurkan S (1996) Removal of mineral matter and sulfur from lignites by alkali treatment. Fuel Process Technol 47(2):99109

Dash PS, Lingam RK, Santosh KS, Suresh A, Banerjee PK, Ganguly $S$ (2015a) Effect of elevated temperature and pressure on the leaching characteristics of Indian coals. Fuel 140:302-308 
Dash PS, Sriramoju SK, Kargupta K, Banerjee PK, Ganguly S (2015b) Characterization of chemical beneficiated Indian coals. Int J Coal Prep Util 35(5):257-272

Ge L, Zhang Y, Wang Z, Zhou J, Cen K (2013) Effects of microwave irradiation treatment on physicochemical characteristics of Chinese low-rank coals. Energy Convers Manag 71:84-91

Georgakopoulos A, Iordanidis A, Kapina V (2003) Study of low rank Greek coals using FTIR spectroscopy. Energy Source Part A Recov Util Environ Effects 25(10):995-1005

Gulen J, Doymaz I, Piskin S, Toprak S (2005) Removal of mineral matter from Silopi-Harput asphaltite by various acid treatment. Energy Source Part A Recov Util Environ Effects 27(15):1457-1464

Ishaq M, Ahmad I, Shakirullah M, Bahader A, Taj N (2002) Characterization of some khushab (Punjab Pakistan) coal. J Chem Soc Pak 24(4):240-245

Jankowski J, Ward CR, French D, Groves S (2006) Mobility of trace elements from selected Australian fly ashes and its potential impact on aquatic ecosystems. Fuel 85(2):243-256

Karaca H, Ceylan K (1997) Chemical cleaning of Turkish lignites by leaching with aqueous hydrogen peroxide. Fuel Process Technol 50(1):19-33

Kumar M, Gupta RC (1997) Demineralization study of Indian Assam coking coal by sodium hydroxide leaching. Energy Source Part A Recov Util Environ Effects 19(7):723-730

Kumar M, Shankar RH (2000) Removal of ash from Indian Assam coking coal using sodium hydroxide and acid solutions. Energy Source Part A Recov Util Environ Effects 22(2):187-196

Ma X, Zhang M, Min F (2014) Study of enhanced low-quality coal oxidative desulphurization and deashing by using $\mathrm{HNO}_{3}$ and microwave pretreatment. Environ Technol 35(1-4):36-41

Meshram P, Purohit BK, Sinha MK, Sahu SK, Pandey BD (2015) Demineralization of low grade coal-a review. Renew Sustain Energy Rev 41:745-761
Miej R (1994) Trace element behavior in coal-fired power plants. Fuel Process Technol 39(2):199-217

Mukherjee S, Borthakur PC (2001) Chemical demineralization/ desulphurization of high sulphur coal using sodium hydroxide and acid solutions. Fuel 80(14):2037-2040

Mukherjee S, Borthakur PC (2003) Effect of leaching high subbituminous coal by potassium hydroxide and acid on removal of mineral matter and sulphur. Fuel 82(7):783-788

Nabeel A, Khan TA, Sharma DK (2009) Studies on production of ultra-clean coal by alkali-acid leaching of low grade coals. Energy Source Part A Recov Util Environ Effects 31(7):594-601

Onal Y, Ceylan K (1995) Effects of treatment on the mineral matter and acidic functional group contents of Turkish lignites. Fuel 74(7):972-977

Ryberg MW, Owsianiak M, Laurent A, Hauschild MZ (2015) Power generation from chemically cleaned coals: do environmental benefits of firing cleaner coal outweigh environmental burden of cleaning? Energy Environ Sci 8:2435-2447

Sahoo BK, De S, Meikap BC (2015) An investigation into the influence of microwave energy on iron ore-water slurry rheology. J Ind Eng Chem 25:122-130

Sharma DK, Gihar S (1991) Chemical cleaning of low grade coals through alkali-acid leaching employing mild conditions under ambient pressure. Fuel 70(5):663-665

Sriramoju SK, Lingam RK, Dash PS (2017) Mechanism of a coal chemical-leaching process and recovery of spent chemicals: a pilot-scale study. Int J Coal Prep Util 37(6):293-302

Waugh AB, Bowling KM (1984) Removal of mineral matter from bituminous coals by aqueous chemical leaching. Fuel Process Technol 9(3):217

Wu Z, Steel KM (2007) Demineralization of a UK bituminous coal using HF and ferric ions. Fuel 86(14):2194-2200 